\title{
Обзоры: конференции
}

УДК 821.161.1

ББК $83.3(2 \mathrm{POC}=\mathrm{PYC})$

DOI 10.22455/2619-0311-2019-4-216-223

Валентина Борисова

\section{O XVII Международном Симпозиуме Достоевского*}

\author{
Valentina Borisova
}

\section{About the $27^{\text {th }}$ International Dostoevsky Symposium}

Об авторе: Валентина Васильевна Борисова, доктор филологических наук, профессор, зав. кафедрой русской литературы БГПУ им. М. Акмуллы (Уфа).

E-mail: borisova@ufacom.ru

Аннотация: Статья представляет собой обзор докладов XVII Международного симпозиума Международного общества Достоевского (14-19 июля, 2019, Бостон). Научный форум был приурочен к 150-летию с момента первой публикации романа «Идиот». В обзоре показаны основные тенденции современного достоевсковедения. Прежде всего, это доклады, продолжающие интерпретационный спор о специфике центрального образа романа и по-прежнему резко разделяющие сторонников «критического» и «апологетического» отношения к князю Мышкину. Также интересны исследования проблем перевода, кросскультурной интерпретации романа, динамики его восприятия в XX-XXI вв. и влияния на современную литературу, междисциплинарные доклады, анализирующие роман с позиций других гуманитарных наук. Значительная часть докладов традиционно была посвящена проблемам поэтики романа, причем, в среде американских исследователей Достоевского, судя по всему, наметилась тенденция к переосмыслению бахтинской методологической традиции. В ряде выступлений освещались результаты исследований философского контекста романа «Идиот» и других текстов Достоевского.

В статье также подчеркивается высокое значение историко-биографических докладов, проливающих свет на неизвестные обстоятельства реального контекста романа «Идиот». Особо в статье выделен ряд методологически новаторских докладов, фактически открывающих новые направления в исследованиях Достоевского. Вслед за виднейшими отечественными и зарубежными учеными автор констатирует высокий

* Исследование выполнено при финансовой поддержке Российского фонда фундаментальных исследований (РФФИ), проект № 18-012-90013 Достоевский / The research was carried out with financial support from Russian Foundation for Basic Research (RFBR), project No.18-012-90013 Dostoevsky. 
научный уровень симпозиума, акцентируя внимание на исключительной ценности подобного научного диалога. В то же время в статье сделан вывод о недостаточно тесных связях между отечественным и англоязычным (прежде всего, американским) достоевсковедением. Во многом совпадая тематически, исследователи разных стран зачастую не знают о результатах работы своих коллег. С этой точки зрения, монотематические научные встречи, подобные бостонскому симпозиуму 2019 года, чрезвычайно полезны.

ключевые слова: Достоевский, Международное общество Достоевского, тематический обзор, интерпретация и восприятие.

Для цитирования: Борисова В.B. O XVII Международном Симпозиуме Достоевского // Достоевский и мировая культура. Филологический журнал. 2019. № 4(8). C. $216-223$

DOI 10.22455/2619-0311-2019-4-216-223

About the author: Valentina V. Borisova, Doctor of Philological Sciences, Professor, Head of the Russian Literature Department of M. Akmullah Bashkir State Pedagogical University (Ufa).

E-mail: borisova@ufacom.ru

Abstract: The article contains an overview of the reports of the XVII International Symposium of the International Dostoevsky Society (July 14-19, 2019, Boston). The scientific forum was dedicated to the 150th anniversary of the first publication of the novel The Idiot. The review shows the main thematic trends of contemporary studies on Dostoevsky. First, the reports continue the dispute about the specifics of the central character of the novel and still sharply divide the sympathizers of the "critical" and "apologetic" view of Prince Myshkin. Another matter of interest is the study of translation problems, cross-cultural interpretation of the novel, dynamics of perception of the novel in the 20th century and its influence on modern literature, interdisciplinary reports analyzing the novel from the standpoint of other humanities. A significant part of the reports has traditionally been devoted to the problems of novel poetics, and it seems that among American researchers there is a tendency to rethink the methodological tradition of Bakhtin. Relatively fewer speeches contained interesting results of studies about the philosophical context of The Idiot and other Dostoevsky's texts.

The article also emphasizes the high significance of historical and biographical reports, which shed light on unknown circumstances of the real context of the novel. The article especially highlights a number of methodologically innovative reports that actually open up new directions in Dostoevsky's research. Following the opinions of the most prominent domestic and foreign scholars, the author states the high scientific level of the symposium, emphasizing the exceptional value of such a scientific dialogue. At the same time, the article concludes that there are not enough close links between domestic and English-speaking (primarily American) studies of Dostoevsky. Researchers from different countries often do not know the works of their colleagues, even when they have common research objects. From this point of view, monothematic scientific meetings, such as the Boston Symposium 2019, can be extremely useful.

Key words: Dostoevsky, International Dostoevsky Society (IDS), thematic review, interpretation and perception.

For citation: Borisova V.V. About the 27th International Dostoevsky Symposium. Dostoevsky and World Culture, Philological journal, 2019, No 4(8), pp. 216-223

DOI 10.22455/2619-0311-2019-4-216-223 
В Бостонском университете (США) 14-19 июля 2019 года состоялся XVII Симпозиум Международного общества Ф.М. Достоевского (International Dostoevsky Society, IDS), посвященный 150-летию романа «Идиот». Организаторами Симпозиума выступили ведущие американские литературоведы: Юрий Корриган (Boston University), Евгения Черкасова (Suffolk University), Вильям Тодд (Harvard University), Светлана Евдокимова (Brown University), Дебора Мартинсен (Columbia University), Кэрол Аполлонио (Duke University), Брайан Армстронг (Augusta University).

120 ученых из США, Великобритании, Венгрии, Швеции, Германии, Польши, Шотландии, Франции, Канады, Италии, Испании, Бельгии, Хорватии, Украины, Болгарии, Австралии, Аргентины, Бразилии, Японии, Китая, в том числе 20 исследователей из России (Москвы, Санкт-Петербурга, Уфы, Ярославля, Томска, Петрозаводска) представили разнообразные, в разной степени эффективные, но заслуживающие внимания подходы к прочтению романа «Идиот». Однако полный обзор всех докладов в данном случае сделать невозможно, поскольку заседания Симпозиума, за исключением пленарных, проходили, как это бывает на всех больших научных форумах, параллельно.

Параллельными, то есть мало пересекающимися, по мнению С.А. Кибальника, который единственный из российских достоевсковедов прочитал свой доклад на английском языке, остаются англоязычное и русскоязычное изучение творчества Достоевского. Действительно, большинству исследователей, за исключением литературоведов-переводчиков (Кэрол Аполлонио, Дебора Мартинсен, Алехандро Гонсалес, Флоренция Гарсиа, Каталин Кроо, Геза Хорват, Евгения Черкасова, Светлана Евдокимова и др.) было трудно, особенно на слух, воспринимать выступления коллег. Некоторым выходом из этой ситуации стали, например, дополнения в виде презентаций на английском языке к докладам, сделанным на русском Еленой Федоровой и Владимиром Захаровым.

Спектр тематических направлений пленарных и секционных заседаний в ходе Симпозиума оказался достаточно репрезентативным для современного состояния изучения жизни и творчества Достоевского в целом и романа «Идиот» в частности. Так, большое количество научных сообщений было посвящено проблемам перевода и рецепции про- 
изведений русского писателя в инокультурной среде. Кэрол Аполлонио («Dostoevsky's Second Century in English») в этой связи убедительно говорила о втором веке Достоевского, имея в виду как сами переводы, так и интерпретации текстов, которые в XXI веке читаются на многих языках мира, о чем шла речь в целой серии других сообщений. Так, Энзая Саркозине (Будапешт) подчеркнула, что при переводе концептов «Бог», «Господь» на монгольский язык неизбежно актуализируется буддистский подтекст и уходит христианский смысл. Профессор Чжоу Гвичао, комментируя четыре варианта перевода фамилии «Мышкин» на китайский язык, отметил, что при всем фонетическом сходстве их семантика различна и связана с разными интерпретациями классического образа, созданного Достоевским, что, по мнению ученого, свидетельствует о его богатых имплицитных возможностях.

По-прежнему показательно для мирового достоевсковедения осмысление опыта восприятия и интерпретации романа в интермедиальном культурном контексте. Большой интерес в этом плане вызвали доклады Елены Мурениной («Опыты прочтения романа на современной сцене»), Тамары Джерманович («Идиот» Тарковского и Достоевского), Анны Зелински-Эллиот («Настасья Вайды и Тамасабуро: интерсемиотический перевод»). Широким по охвату материала был видеодоклад Людмилы Сараскиной «Роман “Идиот” в сценических и экранных воплощениях: история, принципы, мировая практика».

Приоритетными для обсуждения на Симпозиуме стали проблемы интерпретации романа «Идиот» и его главного героя, князя Мышкина. Новые варианты прочтения произведения Достоевского были представлены во многих докладах, неравноценных, однако, по степени научной аргументации. Если, например, Дебора Мартинсен убедительно раскрыла трагедию непрощения в произведении Достоевского, то Наталья Казакова, декларируя бессилие добра в нем, апеллировала в основном к собственным субъективным впечатлениям (показательна ее аргументация «Мне кажется...» и т.п.).

Еще заметней стала предельная поляризация альтернативных прочтений «Идиота», обусловленная, на наш взгляд, рецептивным конфликтом вокруг романа. «Идиот» в современном осмыслении по-прежнему остается в ситуации pro et contra: налицо одновременное выражение и христианской апологии, и демифологизации образа Мышкина. 
С одной стороны, поддерживается и развивается представление о нем как попытке воплотить в художественной реальности образ «положительно прекрасного человека» (Брайан Армстонг, «Dostoevsky's The Idiot as a Critique of the Beautiful Soul»; Валентина Борисова, «Роман Ф. М. Достоевского “Идиот”: история и типология комментирования»; Тамара Баталова, «Поэтика эпилога романа Достоевского “Идиот” и др.), с другой стороны, главный герой развенчивается как воплощение ложного идеала (Джулия Базелика, «Красота, которая не спасет мир»; Денис Жерноклеев, «Нераскаявшаяся Магдалина Достоевского» и др.).

Эта галерея интерпретаций была дополнена другими докладами, в которых анализировалась сама история восприятия романа. Так, Елена Федорова представила исчерпывающее описание прочтений романа в современной российской средней и высшей школе. Рафаэлла Вассена на материале детских изданий 1880-1890-х годов отметила динамику коммерциализации наследия Достоевского. Доклад Томоюки Такахаси был посвящен типологическому сходству оценки Достоевского в «органической» критике Аполлона Григорьева и критике Хидео Кобаяси. Эти доклады объединяет не только интересная и малоосвоенная научной мыслью фактическая основа, но и попытки (в разной степени успешные) концептуализации истории восприятия Достоевского.

Заметной и необходимой альтернативой интерпретационному прочтению текста Достоевского явились доклады источниковедческой и текстологической направленности с добротным фактическим обоснованием основных положений. Образцовыми в этом отношении стали доклады Натальи Тарасовой «Проблемы текстологии романа “Идиот” и Бориса Тихомирова «Творческая предыстория “Идиота”: один роман или два». В них на материале рукописных планов произведения рассмотрена эволюция авторского замысла, сказавшаяся и на эволюции образа главного героя и сюжета.

Традиционно целый ряд докладов был связан с различными аспектами поэтики Достоевского. Так, выступая на первом пленарном заседании («Dostoevsky Writ Small»), Робин Миллер подчеркнула, что каждая концептуальная «мелочь» у Достоевского создает мистическую ауру в его художественной вселенной, функционируя как строительный элемент фантастического реализма писателя. 
Музыкальную семантику имен героев показал Стефано Алоэ в докладе «Ономастика романа “Идиот”», полагая, что имя создает образ, характер. Анализируя поэтику речевого поведения персонажей, Павел Фокин отметил принципиальные особенности индивидуального стиля Достоевского. Фабулу «Идиота» и ее отражения в прозе XXI века рассмотрел Сергей Шаулов, выявляя в ней трансформацию и использование традиции Достоевского.

Были затронуты и проблемы авторского повествования в его различных формах. Так, Слободанка Владив-Гловер, отвечая на вопрос «Как представить непредставимое», оценила искусство рассказывания историй в «Идиоте» на уровне героев-сочинителей. Повествовательные открытия писателя в романе «Идиот» отметил Брайан Эгдорф. О функционировании слова «вдруг» в тексте Достоевского, вызывающего разрыв, повторение и удивление, говорила Ирина Эрман.

Особое внимание было уделено визуальной поэтике автора пятикнижия. Картину Гольбейна в романе «Идиот» как экфрасис описал Людмил Димитров. Елена Быстрова рассмотрела лексемы «на мгновение» и «вдруг» как слова-фиксаторы фотографического мышления Достоевского и, анализируя сцену с китайской вазой, которую разбивает Мышкин, показала, что она включает в себя серию словесных «снимков», разделенных эллипсисами.

Во многих докладах шла речь о литературных подтекстах и литературных диалогах, расширяющих контекст изучения творчества Достоевского. Алехандро Гонсалес («О концепции фантастики у В. Одоевского и Достоевского») убедительно представил Достоевского как достойного наследника родоначальника русской философской фантастики. Большой интерес вызвал доклад Флоренции Брунелли о специфике перевода разговорной речи в произведениях «Живой мертвец» и «Бобок»: даже при использовании международного воровского жаргона она остается непереводимой как стихи.

В секциях «Достоевский и общество», «Восток и Запад» была затронута междисциплинарная проблематика. К примеру, Вадим Шнейдер исследовал роман «Идиот» в экономическом аспекте («Rogozhin's Cash and Epanchin's Factory: The Economic Imaginary of The Idiot»), Джентил де Фариа - с позиции юриспруденции («Law and Capital Punishment in The Idiot»), а Эми Роннер - с позиции современной психологии («The Renunciation of Existence in Dostoevsky’s Writings»). 
В последнем докладе любопытен интерпретационный вывод о том, что поведение Настасьи Филипповны сходно с суицидальным.

Целый ряд научных сообщений был связан с философией и богословием Достоевского. В докладе Сергея Кибальника («If There Is No God Then Anything Is Lawful: Dostoevsky's Meta-Theme in Contemporary European Psychoanalytic Philosophy») знаменитая формула Ивана Карамазова «Если Бога нет, то все позволено» рассмотрена как центральная философская метатема Достоевского. Докладчик показал, какой смысл она обретает в образной структуре романа «Братья Карамазовы» и рассказа «Бобок». Ее новейшие литературно-философские интерпретации, несмотря на определенные искажения авторской мысли, были представлены как значимые попытки постижения современности.

Оригинальный комментарий «Записок из Мертвого дома» в контексте идей французского утопического социализма развернул Сюйян Ми. В сравнительно-типологическом свете прокомментировала «Записки из подполья» и Каталин Кроо. Александра Тоичкина рассмотрела философские претексты зрелого творчества Достоевского в докладе о влиянии на него сочинений немецких философов в переводе Н.Н. Страхова.

К контексту отечественной философии обратилась Анна Резниченко («Русские философы читают Достоевского»), сравнивая, в свою очередь, интерпретации символа заходящего солнца у П.А. Флоренского, С.Н. Дурылина, А.Ф. Лосева и др.

Самое актуальное направление работы Симпозиума было связано с темой Digital Dostoevsky. Так, возможности использования информационных технологий в изучении жизни и творчества Достоевского раскрыл Бенами Баррос, комментируя свой опыт цифровой визуализации языка писателя. На последнем пленарном заседании с докладом и презентацией «Проблемы и перспективы развития проекта Digital Dostoevsky» блестяще выступил Владимир Захаров, рассказав о проекте оцифровки тетрадей и рукописей Достоевского (http:// dostoevsky-archive.ru). По его мнению, рукопись в исследовательских целях информативнее печатного текста. Действительно, многие интерпретационные споры снимаются при обращении к источникам. Были также представлены результаты работы веб-лаборатории и текстологической группы в Петрозаводском университете: на портале 
http://philolog.petrsu.ru размещены конкордансы всех произведений Достоевского, Евангелие писателя с описанием его помет, эпистолярий, архивы журналов «Время», «Эпоха» и «Гражданин», новые собрания сочинений русских писателей-классиков и другие электронные научные издания.

Украшением Симпозиума стала серия концептуальных докладов. Так, Кэрил Эмерсон («Bakhtin's Dostoevsky and the Burden of the Virtues») четко обозначила новое отношение американских ученых к полифонической концепции М.М. Бахтина, учитывающее ее изначальный религиозно-этический подтекст.

Историко-биографический доклад Игоря Волгина «Жена в России больше, чем жена», вызвав всеобщий интерес, заставил задуматься над экстралитературными факторами творческого процесса, в том числе роли писательской жены в нем. В этом отношении А.Г. Достоевская - уникальна. Действительно, «роман “Идиот” должен был быть посвящен ей». Ее особая, именно литературная функция, к тому же этно-конфессиональным образом обусловленная, что подчеркнуто интертекстуальным названием доклада, несомненна.

Органичным дополнением яркого выступления Игоря Волгина стал добротный доклад Ирины Андриановой, которая, развернув широкий литературный контекст, подчеркнула роль жены-стенографистки в творческом процессе Достоевского, выявила особенности стенограмм А.Г. Достоевской, сохранившихся в архивах.

Принципиально новаторским явился доклад Ивана Есаулова «Юродство и шутовство в романе “Идиот”: объяснение, интерпретации, понимание». Ученый, доказывая необходимость расширения и коренного обновления терминологической системы при изучении поэтики Достоевского, реконструировал иерархию ценностей, характерную для русской культуры Нового времени.

В целом, по мнению Вильяма Тодда, XVII Симпозиум Международного общества Ф.М. Достоевского по сравнению с предыдущими продемонстрировал наиболее высокий научный уровень, что подтверждается как размахом его тем, так и глубиной их осмысления, открывающего новые перспективы и горизонты изучения наследия великого русского писателя. 


\section{ДОСТОЕВСКИЙ И МИРОВАЯ КУЛЬТУРА}

\section{Филологический журнал}

\section{9 № 4}

Основан в 2018 г.

Выходит 4 раза в год

Журнал зарегистрирован в Федеральной службе по надзору

в сфере связи и массовых коммуникаций

Свидетельство о регистрации ПИ № ФС77-72614 от 04.04.2018

ISSN 2619-0311

Адрес редакции:

Институт мировой литературы им. А.М. Горького

Российской Академии наук

121069, Москва, ул. Поварская, д. 25а.

e-mail: dostmirkult@yandex.ru

Компьютерная верстка: Н.Э. Чайковская

Дизайн обложки: Д.В. Тихомолова

Подписано в печать 12.12.2019

Формат 60 х 90 1/16. Усл. печ. л. 14,0

Тираж 500 экз.

Отпечатано в ППП «Типография «Наука»

121099 Москва, Шубинский пер., 6

Заказ № 